\title{
Surgical Contraception
}

National Cancer Institute

\section{Source}

National Cancer Institute. Surgical Contraception. NCI Thesaurus. Code C92892.

A method of achieving contraception with the aid of a surgical procedure that prevents fertilization of an egg by a sperm. 